\title{
The first reported case of G6PD deficiency due to Seoul mutation in Poland
}

\author{
Barbara Kaczorowska-Hac • Beata Burzynska • \\ Danuta Plochocka • Katarzyna Zak-Jasinska • \\ Katarzyna Rawa $\cdot$ Elzbieta Adamkiewicz-Drozynska
}

Received: 6 July 2013 / Accepted: 31 August 2013 / Published online: 11 September 2013

(C) The Author(s) 2013. This article is published with open access at Springerlink.com

\section{Dear Editor,}

We present a case of a 6-year-old boy of Polish origin who was diagnosed with glucose-6-phosphate dehydrogenase (G6PD) deficiency due to Seoul mutation. The patient was born prematurely in the 36th week of gestation. There was no history of any hematological disorders in parental families. At birth, it was noted that the patient presented severe hyperbilirubinemia $(19 \mathrm{mg} / \mathrm{dl})$. Infection and serological conflict were ruled out as possible causes of jaundice. At the age of 6 weeks, anemia of prematurity was diagnosed, and due to a $\mathrm{Hb}$ concentration of $7.2 \mathrm{~g} / \mathrm{dl}$, packed red cells were transfused. During infancy, his hemoglobin concentration approximately ranged between 9.5 and $10.5 \mathrm{~g} / \mathrm{dl}$. At the age of 2 years, the boy presented with hemolytic crisis during a rotaviral infection. His full blood count values were as follows: $\mathrm{Hb} 6.9 \mathrm{~g} / \mathrm{dl}, \mathrm{RBC} 2.3 \times 10^{12} / \mathrm{l}$, MCV $92 \mathrm{fl}$, reticulocytes $4 \%$, PLT $436 \times 10^{9} / 1$, WBC $8,464 \times$ $10^{6} / 1$, and bilirubin $2.0 \mathrm{mg} / \mathrm{dl}$. Both direct and indirect antiglobulin tests were negative. There was no hepato- or splenomegaly. Hereditary spherocytosis was excluded using the eosin-5maleimide flow cytometry test. After receiving a packed red cell transfusion and symptomatic treatment, his condition improved. The observation period after treatment was uneventful with hemoglobin concentration, reticulocyte count, and

B. Kaczorowska-Hac $(\bowtie) \cdot$ K. Zak-Jasinska $\cdot$

E. Adamkiewicz-Drozynska

Department of Pediatrics, Hematology and Oncology, Medical University of Gdansk, Debinki 7, 80-952 Gdansk, Poland e-mail: bakaczor@gumed.edu.pl

\section{B. Burzynska $\cdot$ D. Plochocka}

Institute of Biochemistry and Biophysics, Polish Academy of

Science, Pawinskiego 5a, 02-106 Warsaw, Poland

K. Rawa

Department of Pediatrics, Hematology and Oncology, Medical University of Warszawa, Marszalkowska 24, 00-576 Warsaw, Poland bilirubin concentration all normal. At 6 years, he presented with a succeeding severe hemolytic crisis during an upper respiratory tract infection. A $\mathrm{Hb}$ concentration of $3.0 \mathrm{~g} / \mathrm{dl}$ led to a broader diagnostic criteria- G6PD activity was found reduced-1.65 IU/g Hb (norm 13.55 $\pm 2.45 \mathrm{IU} / \mathrm{g} \mathrm{Hb}$ ). Genomic DNA was then isolated using the MagNA Pure Compact Nucleic Acid Isolation Kit I (Roche, Germany). PCR was used to amplify the coding sequence of exons from 9 to 12 of the glucose-6-phosphate dehydrogenase (G6PD) gene. The DNA fragments generated by PCR amplification were purified using the QIAquick PCR Purification (Qiagen, Germany) and directly sequenced with BigDye Terminators and the appropriate primers using an ABI Prism 377 sequencer (Applied Biosystems, CA, USA). The obtained mutation was then confirmed by restriction endonuclease digestion by $D d e I$ (Fermentas, Lithuania). DNA sequencing revealed a 306 Gly $\longrightarrow$ Ser (G6PD Seoul, class 2) mutation (Fig. 1). Moreover, the mother gene mutation carriage was proven.

Currently, the patient is in stable condition presenting with temporary mild hemolysis during sporadic infections. His parents were informed to avoid certain medicines and ingestion of fava bean products.

Although G6PD deficiency is the most common enzyme disorder worldwide, it has rarely been reported among Poles [1-4]. Clinical and numerous other studies of G6PD deficiency demonstrate that the disorder is most prevalent in the Mediterranean area, in Asia, and in Africa [5]. As a result of global population movements, hemoglobin disorders are now increasingly common in the formerly nonindigenous countries of Northern and Western Europe [6]. As far as Poland is concerned, we have not experienced any immigration boom; hence, the incidence of G6PD deficiency is still low. However, Mediterranean mutations predominate herein, and some autochthonic mutations were also reported [3, 4].

Our patient presented with neonatal hyperbilirubinemia and anemia that were interpreted as symptoms of prematurity. 
After his first hemolytic crisis, hereditary spherocytosis, being a more common cause of hemolysis in Central Europe, was excluded [7]. The ultimate and unexpected diagnosis of glucose-6-phosphate deficiency was made after a succeeding hemolytic crisis. Considering the rarity of this disorder in our country, we performed a molecular analysis which revealed a 306Gly->Ser mutation known in literature as the Seoul mutation [8]. Structures of human $\Delta$ G6PD (lack of $25 \mathrm{~N}$ terminal residues) in complex with $\mathrm{NADP}^{+}$and glucose-6phosphate (G6P) have been described by Kotaka et al. [9], PDB entries 2BH9 and 2BHL, respectively. Models of wt and G306S mutated enzymes were built in complex with $\mathrm{NADP}^{+}$and G6P. To check the influence of this mutation on the protein structure, both structures were subjected to energy minimization using AmberFF99 force field as implemented in SYBYLx2.0, Tripos Inc., USA. Residues of the strand $\beta \mathrm{H}$, to which belongs $\mathrm{G} 306$, interact with helix $\alpha_{0}$ and the loop between $\alpha_{0}$ and $\beta O$, so main structural changes are observed in those regions. It is significant as the previously described mutations located there, for example P489L and P489S, belong to class 1 $[10,11]$. The G306S mutation induces changes in structural $\mathrm{NADP}^{+}$as well as G6P sites because a fragment neighboring both regions is affected. We observed changes in orientation of K360, involved in the interaction with G6P, as well as orientations of residues in F237-E239, described as bridging from G6P site to the structural NADP ${ }^{+}$site [9].

We speculate that the appearance of G6PD mutations, previously found in different parts of the world in the Polish population, corroborates that these mutations may have arisen due to separate events, rather than being descendants of individual ancient mutations.

\section{Conclusion}

To the best of our knowledge, this is the first case in the available literature, describing the Seoul mutation in a patient of Polish origin.

Conflict of interest The authors state that they have no competing interests.
Contributions Barbara Kaczorowska-Hac: designed the study and wrote the paper, Beata Burzymska: performed the research, Danuta Plochocka: performed the research, Katarzyna Zak-Jasiniska: analysed the data, Katarzyna Rawa: performed the research, Elzbieta Adamkiewicz-Drozynska: contributed essentials reagents or tools.

Open Access This article is distributed under the terms of the Creative Commons Attribution License which permits any use, distribution, and reproduction in any medium, provided the original author(s) and the source are credited.

\section{References}

1. Glader BE (2008) Glucose-6-phosphate dehydrogenase deficiency and related disorders of hexose monophosphate shunt and glutathione metabolism. In: Windrobe's clinical hematology, 10th. Williams \& Wilkins, Baltimore, pp 1176-1190

2. Beutler E (1994) G6PD deficiency. Blood 84:3613-3636

3. Grabowska D, Jablonska-Skwiecinska E, Plochocka D et al (2004) A novel mutation in the glucose-6-phosphate dehydrogenase gene in a subject with chronic nonspherocytic hemolytic anemiacharacterization of enzyme Rusing yeast expression system and molecular modeling. Blood Cells Mol Dis 32:124-130

4. Jablonska-Skwiecinska E, Lewandowska I, Plochocka D et al (1999) Several mutations including two novel mutations of the glucose-6phosphate dehydrogenase gene in Polish G6PD deficient subjects with chronic nonspherocytic hemolytic anemia, acute hemolytic anemia, and favism. Hum Mutat 14:477-484

5. Cappellini MD, Fiorelli G (2008) Glucose-6-phosphate dehydrogenase deficiency. Lancet 371:64-74

6. Modell B, Darlison M, Birgens H et al (2007) Epidemiology of haemoglobin disorders in Europe: an overview. Scand J Clin Lab Invest 67:39-69

7. Bolton-Maggs PH, Langer JC, Iolascon A et al (2012) Guidelines for the diagnosis and management of hereditary spherocytosis - 2011 update. Br J Haematol 156:37-49

8. Beutler E, Vulliamy TJ, Luzzatto L (2013) Hematologically important mutations: glucose-6-phosphate dehydrogenase. http://www. g6pd/it/G6PDDeficiency-it/ResearchPapers-it/Beutler03-it.aspx

9. Kotaka M, Gover S, Vandeputte-Rutten L et al (2005) Structural studies of glucose-6-phosphate and NADP+ binding to human glucose-6-phosphatedehydrogenase. Acta Crystallogr D Bio Crystallogr 61:495-504

10. Bulliamy T, Luzzatto L, Hirono A et al (1997) Hematologically important mutations: glucose-6-phosphate dehydrogenase. Blood Cells Mol Dis 23:302-313

11. Minucci A, Concolino P, Vendittelli F et al (2008) Glucose-6phosphate dehydrogenase Buenos Aires: a novel de novo missense mutation associated with severe enzyme deficiency. Clin Biochem 41:742-745 